\title{
STATE-OF-THE-ART TIME INTEGRATION METHODS IN THE ADINA PROGRAM
}

\begin{abstract}
This paper presents state-of-the-art solution methods available in the ADINA program for dynamic, direct time integration analysis of time-dependent problems. For implicit direct dynamic solutions, a two-step Bathe method is presented. Advantages of the Bathe method over the widely used Newmark method are shown in small sample problems. Solutions of complex dynamic problems using the Bathe method will be presented at the Conference. For direct explicit dynamic solutions, the Noh-Bathe method is presented and compared with the central difference method and here again, advantages of the Noh-Bathe method are shown in small sample problems.
\end{abstract}

Keywords: structural dynamics, finite elements, implicit time integration, Bathe method, explicit time integration, Noh-Bathe method

\section{Introduction}

Dynamic analysis of engineering structures can be carried out using:

- direct implicit time integration,

- direct explicit time integration, or

- modal solutions.

However, commonly used methods may not remain stable for a given time step in nonlinear solutions. Hence we use in the ADINA program [1] two new methods: one proposed by K.J. Bathe [2],[3] for implicit time integration, which is stable in nonlinear solutions, and the other by G. Noh and K.J. Bathe [4] for explicit time integration, which has advantages over the central difference method. For modal solutions, we use either the Bathe-subspace or Lanczos method. In this presentation we will focus on direct time integration methods only. The material presented here is an effort of the whole ADINA team.

1 Jan Walczak, ADINA R\&D, Inc., Watertown, MA, USA Jan.Walczak@adina.com 


\section{Implicit time integration, Bathe method}

Let us summarize here the essence of the Bathe method. Assuming that the solution is completely known at time $t$ and that we are looking for a solution at time $t+\Delta t$. Let $t+\gamma \Delta t$ be an instant of time between $t$ and $t+\Delta t$, i.e. $\gamma \in(0,1)$. We can then write the equilibrium equation as follows

$$
\mathbf{M}^{t+\gamma \Delta t} \ddot{\mathbf{U}}+\mathbf{C}^{t+\gamma \Delta t} \dot{\mathbf{U}}={ }^{t+\gamma \Delta t} \mathbf{R}-{ }^{t+\gamma \Delta t} \mathbf{F}
$$

Evaluating velocities in terms of displacements and accelerations in terms of velocities, we have [1],[2]:

$$
\begin{aligned}
& { }^{t+\Delta t} \dot{\mathbf{U}}=c_{1}{ }^{t} \mathbf{U}+c_{2}{ }^{t+\lambda \Delta t} \mathbf{U}+c_{3}{ }^{t+\Delta t} \mathbf{U} \\
& { }^{t+\Delta t} \ddot{\mathbf{U}}=c_{1}{ }^{t} \dot{\mathbf{U}}+c_{2}{ }^{t+\gamma \Delta t} \dot{\mathbf{U}}+c_{3}{ }^{t+\Delta t} \dot{\mathbf{U}}
\end{aligned}
$$

where ${ }^{t+\gamma \Delta t} \mathbf{U},{ }^{t+\gamma \Delta t} \dot{\mathbf{U}}$ are displacement and velocity solutions at time $t+\gamma \Delta t$, and

$$
c_{1}=\frac{(1-\gamma)}{\Delta t \gamma} \quad c_{2}=\frac{-1}{(1-\gamma) \gamma \Delta t} \quad c_{3}=\frac{2-\gamma}{(1-\gamma) \Delta t}
$$

Using the above expressions, the equilibrium equation (1) can be written at time $t+\Delta t$ in the following form [1],[2]:

$$
\begin{aligned}
& \left({ }^{t+\Delta t} \mathbf{K}^{(i-1)}+c_{3} c_{3} \mathbf{M}_{-} c_{3} \mathbf{C}\right) \Delta \mathbf{U}^{(i)} \\
& ={ }^{t+\Delta t} \mathbf{R}-{ }^{t+\Delta t} \mathbf{F}^{(i-1)}-\mathbf{M}\left(c_{1}{ }^{t} \dot{\mathbf{U}}+c_{2}{ }^{t+\gamma \Delta t} \dot{\mathbf{U}}+c_{3} c_{1}{ }^{t} \mathbf{U}+c_{3} c_{2}{ }^{t+\gamma \Delta t} \mathbf{U}+c_{3} c_{3}{ }^{t+\Delta t} \mathbf{U}^{(i-1)}\right) \\
& -\mathbf{C}\left(c_{1}{ }^{t} \mathbf{U}+c_{2}{ }^{t+\gamma \Delta t} \mathbf{U}+c_{3}{ }^{t+\Delta t} \mathbf{U}^{(i-1)}\right)
\end{aligned}
$$

Robustness and effectiveness of the Bathe method can be best demonstrated on a simple two degrees of freedom problem representing flexible and stiff parts [1]: 


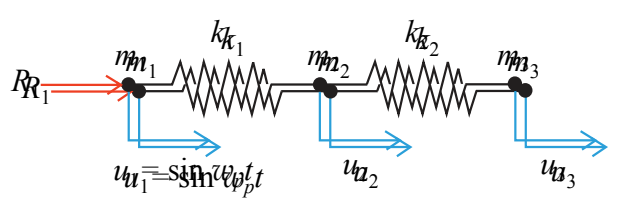

$k_{1}=10^{7}, k_{2}=1, m_{1}=0, m_{2}=1, m_{3}=1, \omega_{p}=1.2$

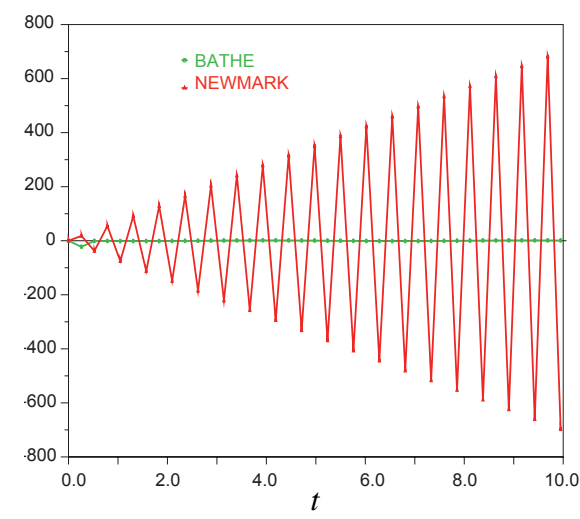

Fig. 1. A simple, 2DOF problem, presented in [1]

Rys. 1. Prosty przykład, dwa stopnie swobody [1]

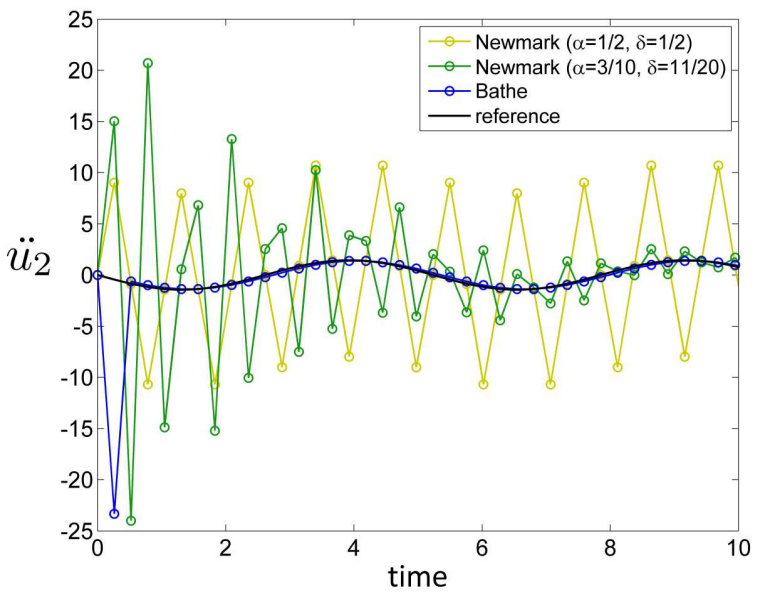

Fig. 2. Close-up of accelerations at node 2

Rys. 2. Zbliżenie rysunku 1, przyspieszenia w węźle 2

As can be seen from the above graph, the Newmark method becomes unstable after a few time steps. Fig. 2 shows a close-up of acceleration of node 2. For nonlinear problems, incorrect accelerations may lead to convergence difficulties, especially for contact problems.

The Bathe method has been used in many applications and, at the Conference, solutions will be presented for complex structures, namely earthquake analysis of tall bridges, analysis of crushed car components and dynamic solutions of fluid-structure interaction (FSI) problems. 


\section{Explicit time integration, Noh-Bathe method}

The central difference method is commonly used for explicit time integration. The difficulties with the central difference method are spurious oscillations, present even when the optimal time step is used, i.e. if CFL number is equal to 1.0 , where $C F L=\Delta t / \Delta t_{r}$.

Considering linear analysis, the governing finite element equations to be solved are:

$$
\mathbf{M U ̈}+\mathbf{C} \dot{\mathbf{U}}+\mathbf{K U}=\mathbf{R}
$$

where $\mathbf{M}, \mathbf{C}, \mathbf{K}$ are the mass, damping and stiffness matrices. The NohBathe method [3] consists of two sub-steps, similar to the Bathe implicit method. The time step sizes are $p \Delta t$ and $(1-p) \Delta t$ for the first and the second sub-step, respectively, where $p \in(0,1)$. The first sub-step can be solved as follows:

$$
\begin{aligned}
& \mathbf{M}^{t+p \Delta t} \mathbf{U}+\mathbf{C}^{t+p \Delta t} \dot{\mathbf{U}}+\mathbf{K}^{t+p \Delta t} \mathbf{U}={ }^{t+p \Delta t} \mathbf{R} \\
& { }^{t+p \Delta t} \mathbf{U}={ }^{t} \mathbf{U}+[p \Delta t]{ }^{t} \mathbf{U}+\frac{1}{2}[p \Delta t]^{2 t} \ddot{\mathbf{U}} \\
& { }^{t+p \Delta t} \ddot{\mathbf{U}}={ }^{t+p \Delta t} \mathbf{R} / \mathbf{M} \\
& { }^{t+p \Delta t} \dot{\mathbf{U}}={ }^{t} \mathbf{U}+\frac{1}{2} p \Delta t\left[{ }^{t} \ddot{\mathbf{U}}+{ }^{t+p \Delta t} \ddot{\mathbf{U}}\right]
\end{aligned}
$$

For the second sub-step we have:

$$
\begin{aligned}
& \mathbf{M}^{t+\Delta t} \ddot{\mathbf{U}}+\mathbf{C}^{t+\Delta t} \dot{\mathbf{U}}+\mathbf{K}^{t+\Delta t} \mathbf{U}={ }^{t+\Delta t} \mathbf{R} \\
& { }^{t+\Delta t} \mathbf{U}={ }^{t+p \Delta t} \mathbf{U}+[(1-p) \Delta t]^{t+p \Delta t} \dot{\mathbf{U}}+\frac{1}{2}[(1-p)]^{2 t+p \Delta t} \ddot{\mathbf{U}} \\
& { }^{t+\Delta t} \ddot{\mathbf{U}}={ }^{t+\Delta t} \mathbf{R} / \mathbf{M} \\
& { }^{t+\Delta t} \dot{\mathbf{U}}={ }^{t+p \Delta t} \dot{\mathbf{U}}+a_{5}{ }^{t} \ddot{\mathbf{U}}+a_{6}{ }^{t+p \Delta t} \ddot{\mathbf{U}}+a_{7}{ }^{t+\Delta t} \ddot{\mathbf{U}} \\
& \text { where: } a_{5}=q_{0}(1-p) \Delta \mathrm{t} \quad a_{6}=\left(\frac{1}{2}+q_{1}\right) \quad a_{7}=q_{2}(1-p) \Delta t
\end{aligned}
$$




$$
q_{1}=\frac{1}{2}(1-2 p) /(p(1-p)) \quad q_{2}=\frac{1}{2}-p q_{1} \quad q_{0}=\frac{1}{2}-q_{1}-q_{2}
$$

To illustrate the predictive capabilities of the Noh-Bathe method, we consider a pre-stressed membrane [3], for which we compare the central difference method and Noh-Bathe method wave propagation solutions.

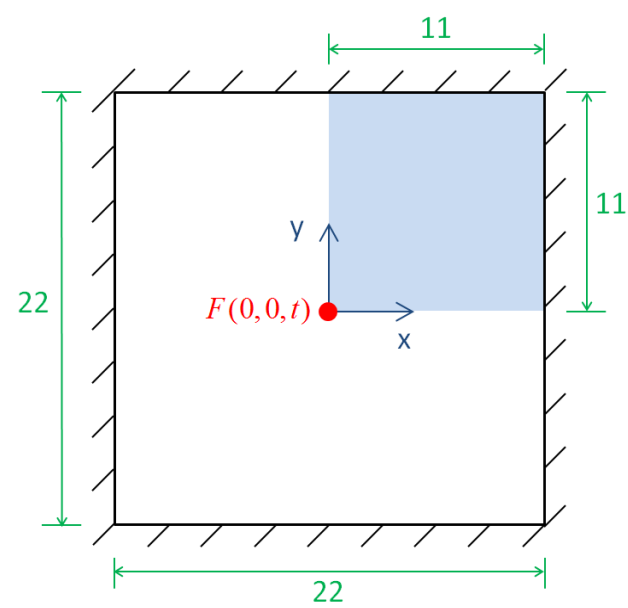

Fig. 3. Pre-stressed membrane problem; initial displacement and velocity are zero

Rys. 3. Naprężona membrana, początkowe przemieszczenia i prędkości równe zero

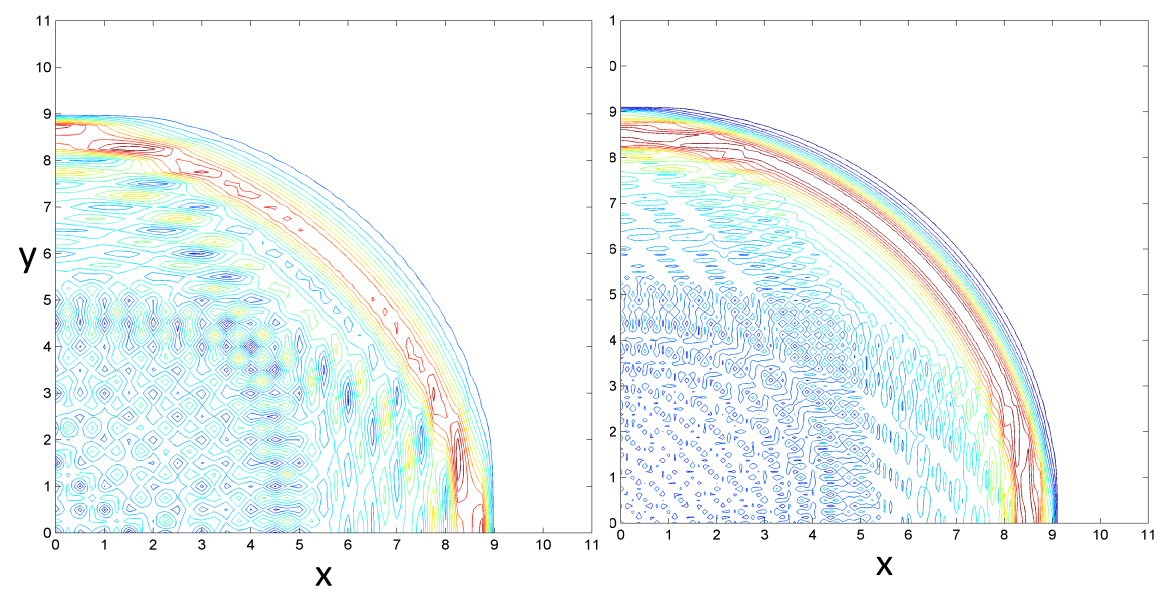

Fig. 4. Central difference displacement response, left: $44 \times 44$ mesh, right: $88 x 88$ mesh Rys. 4. Metoda różnic centralnych, przemieszczenia, siatki po lewej: 44x44, po prawej 88x88 

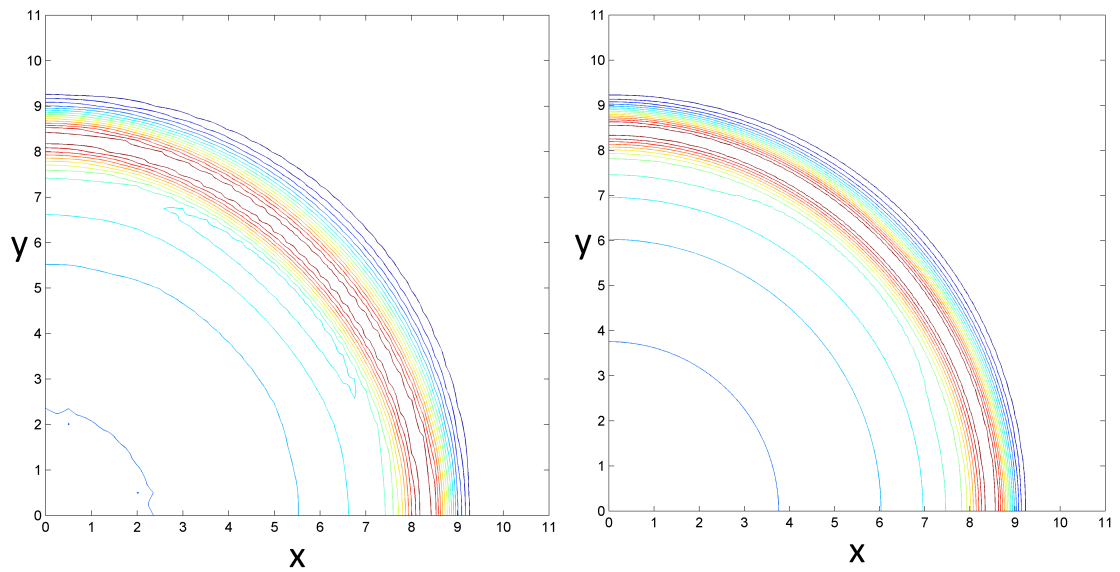

Fig. 5. Noh-Bathe displacement response, left: $44 \times 44$ mesh, right: $88 \times 88$ mesh

Rys. 5. Metoda Noh-Bathe, przemieszczenia, siatki po lewej: 44x44, po prawej 88x88

\section{Implicit and explicit solutions of a compressed tube}

In engineering practice, crush and crash simulations are almost always performed using explicit time integration. Crash events are quite rapid events, occurring over relatively small time periods; hence, a small time step explicit time integration simulation of the problem is naturally pursued. On the other hand, crush events are slow dynamic events, occurring over relatively large time periods. They are frequently almost static events. These simulations, when performed with explicit time integration, require mass scaling and careful setting or tuning of parameters in order to obtain valid solutions.

One of our continuing aims in the ADINA developments has been to establish an analysis tool that can be used reliably and effectively for both crash and crush simulations, i.e. to use implicit integration or explicit integration, whichever technique is most appropriate, based on the physics of the problem. One important feature in the ADINA program is a possibility to automatically switch from implicit time integration to explicit time integration (e.g. when there is no convergence) or from explicit time integration to implicit time integration (e.g. to calculate spring back). 


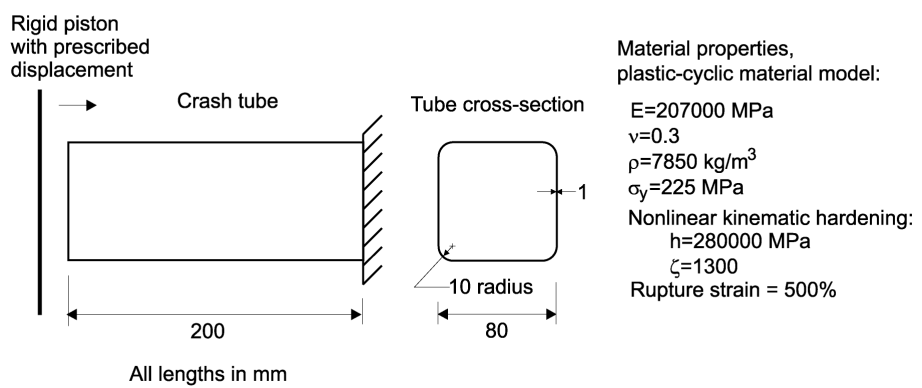

Fig. 6. Crush tube geometry and material data

Rys. 6. Zgniatanie prostokątnej tuby, dane materiałowe i geometryczne

Let us consider a crush tube process, shown on Fig. 6, with the piston motion at $1 \mathrm{mph}$ and at $30 \mathrm{mph}$. The $1 \mathrm{mph}$ case is solved using implicit time integration. The $30 \mathrm{mph}$ case is solved twice, first using implicit time integration (Bathe method) and in a second run, using explicit time integration (Noh-Bathe method).The tube has been modeled using 3D-shell MITC4 elements and large strain assumptions and the same mesh, model and material data are used for both cases.

The resulting force deflection curves are shown in Fig. 7. Note that peak forces calculated in the explicit and implicit solutions are practically the same for the $30 \mathrm{mph}$ case, and overall responses after the peak forces have been reached are similar.

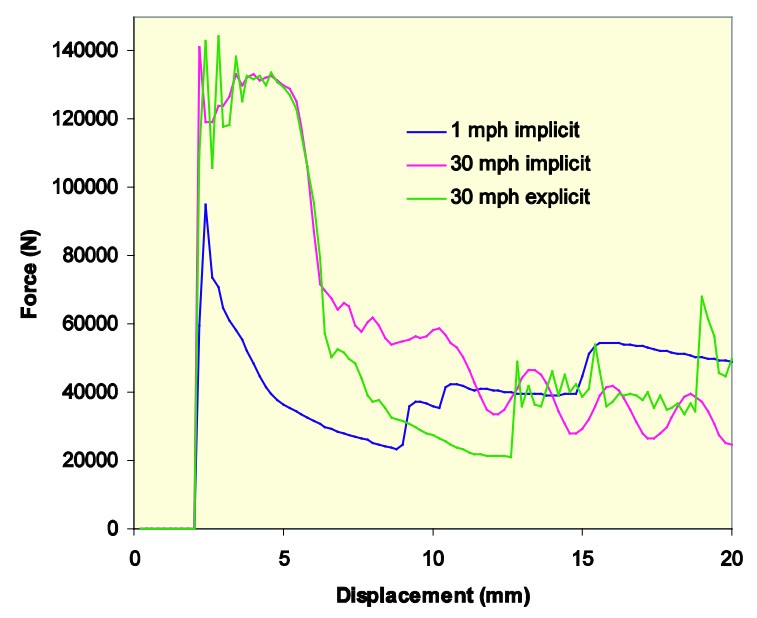

Fig. 7. Force deflection responses for a compressed tube Rys. 7. Wykres siła-przemieszczenie dla ściskanej tuby 


\section{Conclusion}

The ADINA program provides reliable, state-of-the-art tools for dynamic analysis of structures. In particular, the Bathe method shows very desirable solution characteristics in implicit direct time integration solutions. The high frequency response is effectively damped out, leading to better convergence in nonlinear solutions. The advantages of Bathe method and Noh-Bathe method have been shown using simple illustrative examples. Solution results for complex structures will be presented at the Conference.

\section{References}

[1] K.J. Bathe, G. Noh, Insight into implicit time integration scheme for structural dynamics, Computer \& Structures, 98-99, 2012, s. 1-12.

[2] G. Noh, K.J. Bathe, An Explicit Time Integration Scheme for the Analysis of Wave Propagation, Computers \& Structures, 129, 2013, s. 178-193.

[3] ADINA Theory and Modeling Guide, ADINA R\&D, Inc, Watertown MA, 2011.

[4] K.J. Bathe, Conserving energy and momentum in nonlinear dynamics: a simple implicit time integration scheme, Computers \& Structures, 85, 2007, s. 437-445.

\section{STAN WIEDZY NA TEMAT METOD CALKOWANIA ROWNAN RUCHU W PROGRAMIE ADINA}

\footnotetext{
Streszczenie

W pracy zaprezentowano metody do bezpośredniego całkowania równań ruchu schematem niejawnym (metoda Bathe'go) i jawnym (metoda Noh-Bathe). W przypadku niejawnego schematu rozwiazywania równań ruchu, porównano rezultaty otrzymane metodami Bathe'go i Newmarka dla prostych przykładów uwypuklając przewagę metody Bathe'go. W przypadku jawnego schematu rozwiazywania równań ruchu, porównano wyniki otrzymane przy pomocy metody NohBate i metody różnic centralnych. Wyniki rozwiązań dla kompleksowych konstrukcji będą przedstawione w czasie Konferencji.
}

Słowa kluczowe: dynamika konstrukcji, niejawne rozwiazywanie równań ruchu, metoda Bathe'go, jawne rozwiazywanie równań ruchu, metoda Noh-Bathe

Przestano do redakcji: 24.02 .2017 r.

Przyjęto do druku: 28.04.2017 r. 